\section{Nuclear Bangladesh} \section{Umbrella agreement}

\section{Dacca}

Bangladesh and the United States have entered into an umbrella agreement for cooperation on the peaceful uses of nuclear energy. The agreement also provides for exchange of knowledge, expertise and equipment.

The United States has agreed to export a 3 megawatt Triga Mark-II research reactor. This will be installed at Savar, about 25 miles north of Dacca and is expected to go into operation in the first half of 1983. It will be purchased by Bangladesh Atomic Energy Commission at a cost of Taka 500 million or approximately US $\$ 26$ million on a cash payment basis; an advance of Taka 22.0 million has already been paid to the manufacturer (General Atomic Company). The agreement, for an initial period of ten years which may be extended with the approval of both governments, covers the design, development, construction, operation, maintenance and use of reactors, nuclear fuel disposal, health and safety measures, production and use of radioisotopes in medicine, agriculture and industry. It also includes the exploration and development of nuclear minerals in Bangladesh.

At the signing of the agreements the United States Ambassador to Bangladesh Mrs Jane Abell Coon, recalled that the United States welcomed the accession of Bangladesh in 1979 to the international treaty on the non-proliferation of nuclear weapons.

M. Kabir

\section{Nuclear Yugoslavia}

\section{Balkans balkanized}

Yugoslavia's first nuclear power station, at Krsko on the Croatian-Slovenian frontier, has at last been completed. A selfsustaining reaction was achieved on 11 September, and low-po ver tests are now in progress.

Public concern about reactor safety, has presumably been allayed by legislation passed in August dealing with all aspects of nuclear power plant operation. Recent restrictions on power consumption have also done much to swing local opinion back in favour of the Krsko reactor.

Completion of the station, which was built in cooperation with Westinghouse and cost some $\$ 600$ million, was more than three years behind schedule, a delay usually attributed to Yugoslavia's lack of transport and construction infrastructure. The Federal Premier, Veselin Djuranovic, however, has blamed construction schedules which, he has said, must from now on be realistically drawn up and properly adhered to. Out of ten power stations scheduled for commissioning in 1981 , he said, only one was actually ready.

\title{
Loading up for Brazilian power
}

\section{Rio de Janeiro}

Angra I, the first Brazilian nuclear plant - a standard 620 megawatt Westinghouse reactor - has just started loading its 50 tons of enriched uranium rods, some five years behind schedule. At the same time, the president of FURNAS, the electrical company of Rio de Janeiro, has announced a forthcoming increase in electricity rates to "dilute" the $\$ 1,300$ million cost. When started, this project was due to cost $\$ 300$ per kilowatt; each installed kilowatt has so far cost the Brazilians more than $\$ 2,000$.

The unit will reach full power by the end of 1981. Westinghouse's personnel will remain on site for one more year the extent of the guarantee. After that, operations will be suspended for a month to permit partial refuelling with fuel imported from the United States.

The importation of enriched uranium from the United States continues to create diplomatic squabbles between the American government, attempting to impose strict safeguards, and Brazilian

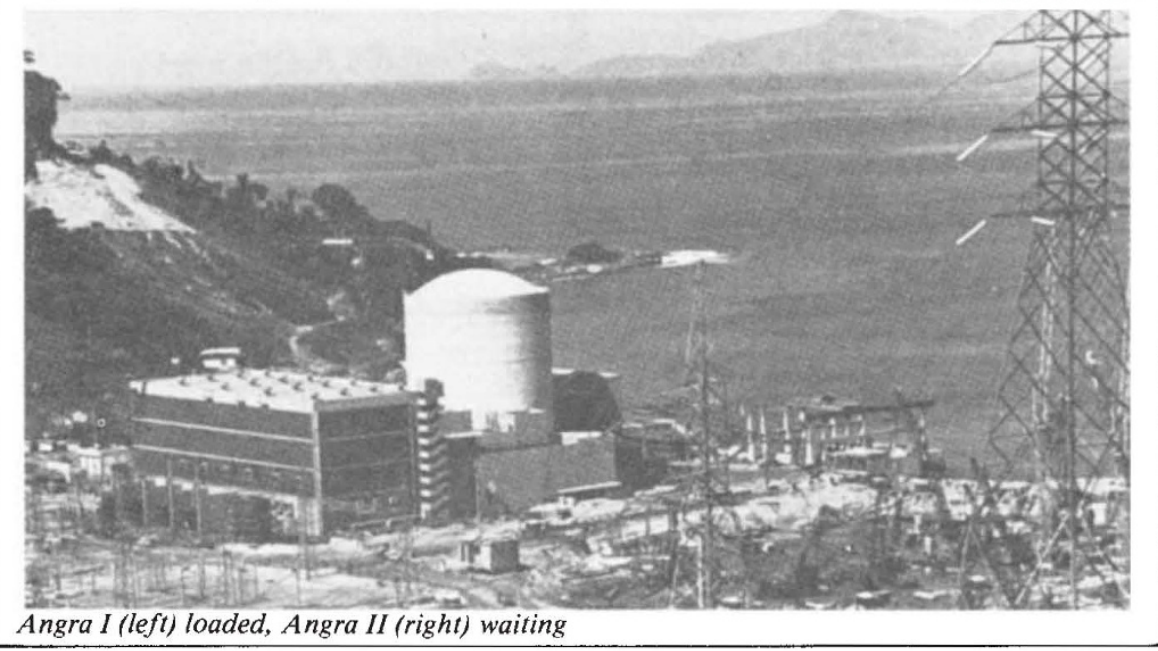

The Premier was visiting the Djerdap (Iron Gates) hydroelectric power station spanning the Danube and built jointly with Romania. Djerdap-1 was commissioned in 1971; Djerdap-2, some $80 \mathrm{~km}$ downstream, is still being built and should be commissioned in late 1983 or early 1984 . The delays plus the economic recession, which has reduced the country's capacity to import oil and coal, have brought the country's power situation to a point which power engineers at Djerdap described to the Premier as "very critical".

A complication is that Yugoslavia's power industry is organized independently by each republic. Of the three "developed" republics, Slovenia is fairly well-placed, having its own uranium, and the chance, if currency permits, of importing electricity from Austria. Croatia, which already has a share in Krsko, is planning at least two more nuclear power stations.

In Serbia, however, the hydroelectric potential is already 75 per cent exploited. government still refusing to sign the NonProliferation Treaty.

So far, though, there is no disposal site for the spent reactor fuel, public protests having forced the abandonment of the initial choice - a vegetable growing valley above Rio de Janeiro. As a temporary measure the spent fuel rods will be stored in the reactor building itself. Low radioactivity waste will probably be stored on an island off Angra's shore.

The other Brazilian nuclear plants, to be built as part of the German-Brazilian contract (see Nature 284, 656; 1980), are still a long way off. The 1,200 megawatt Angra II, situated on the same beach as Angra I (left) loaded up, Angra II (right) still waiting for its concrete floor slab to be poured on top of the 300 cement columns built through the sand to reach rock bottom. Its cost, however, keeps rocketing, having already reached $\$ 700$ million merely for its foundations; the officially anticipated final cost is $\$ 2,700$ per kilowatt delivered.

Maurice Bazin

Coal reserves in Serbia proper are running out (although the would-be-breakaway Autonomous Province of Kosovo still has significant amounts of coal). According to Mileta Jasic, head of the management committee of the republic's Community of Interest for the Power Economy, the "permanent solution" lies in nuclear power (the first nuclear station, he said, could be started in 1990) together with joint undertakings with other republics.

Such cooperation is essential as this republic-based organization can lead to discrepancies. In particular, Yugoslavia's drive to save electricity is being implemented in a rather piecemeal manner. In Croatia, television programmes are closing down early, in Montenegro there has been a flat reduction of 10 per cent to all consumers, while Serbia has introduced a weekly quota — anyone exceeding it will have his next quota docked by an equivalent amount.

Vera Rich 